\title{
Neuroprotective Diterpenes from the Fruiting Body of Antrodia camphorata
}

\author{
Cheng-Chi Chen, ${ }^{\dagger}$ Young-Ji Shiao,${ }^{\ddagger}$ Ruei-Da Lin, ${ }^{\dagger}$ Yi-Yuan Shao, ${ }^{\S}$ Min-Nan Lai, ${ }^{\perp}$ Chun-Ching Lin,,${ }^{\Perp}$ Lean-Teik Ng, ${ }^{\nabla}$ and \\ Yueh-Hsiung Kuo*,† \\ Department of Chemistry, National Taiwan University, Taipei, Taiwan 106, National Research Institute of Chinese Medicine, Taipei, Taiwan \\ 112, Department of Food Science, Nutrition and Nutraceutical Biotechnology, Shih Chien University, Taipei, Taiwan 104, Kang Jian Biotech \\ Corp., Ltd., Nantou, Taiwan 542, Graduate Institute of Natural Products, College of Pharmacy, Kaohsiung Medicine University, Kaohsiung, \\ Taiwan 807, and Department of Biotechnology, Ta Jen University, Pintung, Taiwan 907, Republic of China
}

Received November 28, 2005

Three new compounds, 19-hydroxylabda-8(17)-en-16,15-olide (1), 3 $\beta$,19-dihydroxylabda-8(17),11E-dien-16,15-olide (2), and 13-epi-3 $\beta, 19$-dihydroxylabda-8(17),11E-dien-16,15-olide (3), together with four known compounds, 19hydroxylabda-8(17),13-dien-16,15-olide (4), 14-deoxy-11,12-didehydroandrographolide (5), 14-deoxyandrographolide, and pinusolidic acid, were isolated from the fruiting bodies of Antrodia camphorata. The structures of compounds 1-3 were elucidated by the analysis of their spectroscopic data. The in vitro neuroprotective activity of all compounds was evaluated, and compounds $\mathbf{1} \mathbf{- 5}$ protected neurons from $\mathrm{A} \beta$ damage by $39.2,35.0,36.7,30.6$, and $27.0 \%$, respectively, at concentrations between 5 and $20 \mu \mathrm{M}$.

Antrodia camphorata Wu, Ryvarden \& Chang (Polyporaceae, Aphyllophorales) is a parasitic fungus on the inner heartwood wall of the endemic species Cinnamomum kanehirai Hay (Lauraceae), which is an endangered species in Taiwan. Because the growth rate of natural $A$. camphorata in the wild is very slow and it is difficult to cultivate in a greenhouse, the fruiting bodies are rare and expensive. Traditionally, this fungus has been used as a Chinese remedy for food and drug intoxication, diarrhea, abdominal pain, hypertension, itching of the skin, and liver cancer. ${ }^{1}$ In biological studies, the fruiting bodies exhibited immunomodulating, ${ }^{2}$ antioxidative, ${ }^{3}$ and hepatoprotective effects. ${ }^{3}$ The cultured mycelia have shown anti-inflammatory activity, ${ }^{4}$ vasorelaxation, ${ }^{5}$ cytotoxic activity against several tumor cell lines, ${ }^{6-8}$ protection of oxidative damage in normal human erythrocytes, ${ }^{8}$ and anti-hepatitis B virus activity. ${ }^{9}$ The only chemical study of the cultured mycelia of $A$. camphorata was conducted by Nakamura et al., in which five cytotoxic maleic and succinic acid derivatives were found. ${ }^{7}$ Previous chemical studies of the fruiting body of $A$. camphorata have led to reports of several components including fatty acids, lignans, phenyl derivatives, sesquiterpenes, steroids, and triterpenoids. ${ }^{10-16}$ In this paper, we report the isolation and structural elucidation of three new labdane diterpenoids $(\mathbf{1}-\mathbf{3})$ from the fruiting body of $A$. camphorata. These compounds and four compounds of known structure were evaluated for their neuroprotective effects in an in vitro test system.

The methanol extract of $A$. camphorata was partitioned with EtOAc and $\mathrm{H}_{2} \mathrm{O}$. The EtOAc-soluble fraction was chromatographed repeatedly to afford three new compounds, $\mathbf{1 - 3}$, along with four known labdane diterpenoids, 19-hydroxylabda-8(17),13-dien-16,15olide (4), ${ }^{17}$ 14-deoxy-11,12-didehydroandrographolide (5), ${ }^{18-21} 14$ deoxyandrographolide, ${ }^{18-20}$ and pinusolidic acid. ${ }^{22}$ The structures of the known compounds were established by comparison of their spectroscopic data with literature values.

Compound 1 was isolated as an amorphous powder, and its molecular formula of $\mathrm{C}_{20} \mathrm{H}_{32} \mathrm{O}_{3}$ was established through analysis of its ${ }^{13} \mathrm{C}$ NMR (Table 1) and HREIMS data. The IR spectrum of 1 confirmed the presence of a $\gamma$-lactone group $\left(1772 \mathrm{~cm}^{-1}\right)$ and a

* To whom correspondence should be addressed. Tel: 886-2-33661672. Fax: +886-2-23636359. E-mail: yhkuo@ntu.edu.tw.

$\dagger$ National Taiwan University.

National Research Institute of Chinese Medicine.

$\S$ Shih Chien University.

$\perp$ Kang Jian Biotech Corp., Ltd.

"Kaohsiung Medicine University.

$\nabla$ Ta-Jen University.

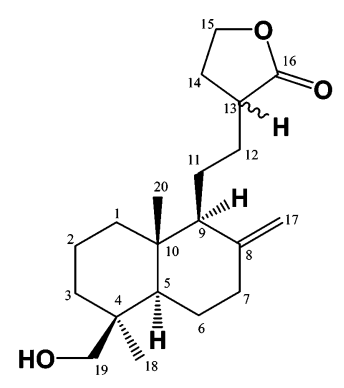

1

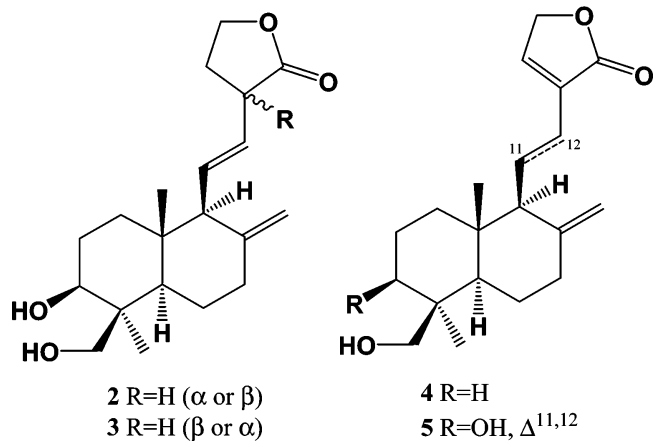

hydroxyl group $\left(3470 \mathrm{~cm}^{-1}\right)$. The ${ }^{1} \mathrm{H}$ NMR spectrum (Table 1) exhibited signals for two primary methyl groups $\left[\delta_{\mathrm{H}} 0.62\right.$ and 0.95 (3H each, s)], two methylene protons linked to a $\gamma$-lactone group $\left[\delta_{\mathrm{H}} 4.16(\mathrm{td}, J=8.8,6.8 \mathrm{~Hz})\right.$ and $\left.4.30(\mathrm{td}, J=8.8,2.8 \mathrm{~Hz})\right]$, a pair of olefinic protons $\left[\delta_{\mathrm{H}} 4.50\right.$ and $4.80(1 \mathrm{H}$ each, br s)], and two germinal carbinol protons $\left[\delta_{\mathrm{H}} 3.36\right.$ and $3.72(1 \mathrm{H}$ each, $\mathrm{d}, J=$ 11.2 Hz)]. The ${ }^{1} \mathrm{H}$ NMR data were almost the same as those of known compound 4 except for that of $\mathrm{H}_{2}-15$ and one more olefinic proton for $4 .{ }^{17}$ The consecutive protons from $\delta_{\mathrm{H}} 1.0$ to 2.0 were revealed from the COSY and the HMBC spectra and clarified their relative locations. The ${ }^{13} \mathrm{C}$ NMR data (Table 1) and DEPT spectroscopic analysis showed 20 signals including two $\mathrm{CH}_{3}, 11$ $\mathrm{CH}_{2}$, three $\mathrm{CH}$, and three $\mathrm{C}$ carbons and one lactone carbonyl carbon. The lactone carbonyl carbon was assigned to $\mathrm{C}-16$ on the basis of the HMBC spectrum. The two methylene protons linked to the $\gamma$-lactone group were correlated to $\mathrm{C}-13$ at $\delta_{\mathrm{C}} 39.5, \mathrm{C}-14$ at $\delta_{\mathrm{C}} 29.6$, and $\mathrm{C}-16$ at $\delta_{\mathrm{C}} 179.1$. In the same experiment, interactions were evidenced between the $\mathrm{H}_{2}-19$ methylene protons at $\delta 3.36$ and 3.72 and the carbons $\mathrm{C}-3$ at $\delta 35.4, \mathrm{C}-4$ at $\delta 39.6, \mathrm{C}-5$ at $\delta$ 
Table 1. NMR Data $\left(\mathrm{CDCl}_{3}, 400 \mathrm{MHz}\right)$ for Compounds $\mathbf{1}-\mathbf{3}$ [ $\delta$ in ppm, mult. $(J$ in $\left.\mathrm{Hz})\right]$

\begin{tabular}{|c|c|c|c|c|c|c|}
\hline \multirow[b]{2}{*}{ position } & \multicolumn{2}{|r|}{1} & \multicolumn{2}{|r|}{2} & \multicolumn{2}{|r|}{3} \\
\hline & $\delta_{\mathrm{C}^{a}}^{a}$ & $\delta_{\mathrm{H}}$ & $\delta_{\mathrm{C}^{a}}$ & $\delta_{\mathrm{H}}$ & $\delta_{\mathrm{C}^{a}}$ & $\delta_{\mathrm{H}}$ \\
\hline \multirow[t]{2}{*}{1} & $39.0 \mathrm{t}$ & $1.05 \operatorname{td}(13.2,5.2)$ & $38.2 \mathrm{t}$ & $1.10 \operatorname{td}(14.0,4.4)$ & $38.3 \mathrm{t}$ & $1.12 \operatorname{td}(13.2,4.8)$ \\
\hline & & $1.58 \mathrm{~m}$ & & $1.45 \mathrm{dt}(14.0,3.6)$ & & $1.60 \mathrm{dt}(13.2,4.0)$ \\
\hline \multirow[t]{2}{*}{2} & $19.0 \mathrm{t}$ & $1.56 \mathrm{~m}$ & $23.0 \mathrm{t}$ & $1.75 \mathrm{~m}$ & $23.3 \mathrm{t}$ & $1.80 \mathrm{~m}$ \\
\hline & & $1.82 \mathrm{~m}$ & & $1.29 \mathrm{~m}$ & & $1.29 \mathrm{~m}$ \\
\hline \multirow[t]{2}{*}{3} & $35.4 \mathrm{t}$ & $1.31 \mathrm{~m}$ & $80.7 \mathrm{~d}$ & $3.45 \mathrm{dd}(11.2,4.4)$ & $80.8 \mathrm{~d}$ & $3.46 \mathrm{dd}(11.2,5.2)$ \\
\hline & & $1.89 \mathrm{~m}$ & & & & \\
\hline 4 & $39.6 \mathrm{~s}$ & & $42.9 \mathrm{~s}$ & & $43.2 \mathrm{~s}$ & \\
\hline 5 & $57.1 \mathrm{~d}$ & $1.22 \mathrm{dd}(12.8,2.4)$ & $54.6 \mathrm{~d}$ & $1.15 \mathrm{dd}(12.8,2.0)$ & $54.8 \mathrm{~d}$ & $1.16 \mathrm{dd}(12.8,2.4)$ \\
\hline \multirow[t]{2}{*}{6} & $24.4 \mathrm{t}$ & $1.77 \mathrm{~m}$ & $28.2 \mathrm{t}$ & $1.70 \mathrm{~m}$ & $28.5 \mathrm{t}$ & $1.71 \mathrm{~m}$ \\
\hline & & $1.79 \mathrm{~m}$ & & $1.72 \mathrm{~m}$ & & $1.73 \mathrm{~m}$ \\
\hline \multirow[t]{2}{*}{7} & $38.5 \mathrm{t}$ & $1.98 \mathrm{~m}$ & $36.5 \mathrm{t}$ & $2.00 \operatorname{td}(12.8,4.8)$ & $36.8 \mathrm{t}$ & $2.00 \mathrm{td}(13.2,4.4)$ \\
\hline & & $2.37 \mathrm{~m}$ & & $2.40 \mathrm{brd}(12.8)$ & & $2.41 \mathrm{brd}(12.4)$ \\
\hline 8 & $147.4 \mathrm{~s}$ & & $148.1 \mathrm{~s}$ & & $148.0 \mathrm{~s}$ & \\
\hline 9 & $56.3 \mathrm{~d}$ & $2.34 \mathrm{~m}$ & $60.4 \mathrm{~d}$ & $2.26 \mathrm{~d}(9.6)$ & $60.5 \mathrm{~d}$ & $2.26 \mathrm{~d}(10.0)$ \\
\hline 10 & $38.9 \mathrm{~s}$ & & $38.1 \mathrm{~s}$ & & $38.5 \mathrm{~s}$ & \\
\hline \multirow[t]{2}{*}{11} & $21.4 \mathrm{t}$ & $1.42 \mathrm{~m}$ & $131.5 \mathrm{~d}$ & $5.64 \mathrm{dd}(15.6,9.6)$ & $131.9 \mathrm{~d}$ & $5.67 \mathrm{ddd}(15.2,10.0,1.2)$ \\
\hline & & $1.50 \mathrm{~m}$ & & & & \\
\hline 12 & $28.9 \mathrm{t}$ & $\begin{array}{l}1.24 \mathrm{~m} \\
1.46 \mathrm{~m}\end{array}$ & $127.1 \mathrm{~d}$ & $5.50 \mathrm{dd}(15.6,5.6)$ & $127.0 \mathrm{~d}$ & $5.44 \mathrm{dd}(15.2,6.8)$ \\
\hline 13 & $39.5 \mathrm{~d}$ & $2.46 \mathrm{~m}$ & $42.2 \mathrm{~d}$ & $3.24 \mathrm{~m}$ & $42.9 \mathrm{~d}$ & $3.25 \mathrm{~m}$ \\
\hline \multirow[t]{2}{*}{14} & $29.6 \mathrm{t}$ & $1.75 \mathrm{~m}$ & $29.1 \mathrm{t}$ & $2.45 \mathrm{~m}$ & $29.7 \mathrm{t}$ & $2.46 \mathrm{~m}$ \\
\hline & & $1.96 \mathrm{~m}$ & & $2.15 \mathrm{~m}$ & & $2.14 \mathrm{~m}$ \\
\hline \multirow[t]{2}{*}{15} & $66.4 \mathrm{t}$ & $4.16 \operatorname{td}(8.8,6.8)$ & $66.5 \mathrm{t}$ & $4.34 \operatorname{td}(8.4,3.6)$ & $66.6 \mathrm{t}$ & $4.35 \operatorname{td}(9.2,4.0)$ \\
\hline & & $4.30 \operatorname{td}(8.8,2.8)$ & & $4.23 \operatorname{td}(8.4,6.8)$ & & $4.23 \operatorname{td}(9.2,6.8)$ \\
\hline 16 & $179.1 \mathrm{~s}$ & & $177.1 \mathrm{~s}$ & & $176.6 \mathrm{~s}$ & \\
\hline \multirow[t]{2}{*}{17} & $106.7 \mathrm{t}$ & $4.50 \mathrm{br} \mathrm{s}$ & $108.8 \mathrm{t}$ & $4.74 \mathrm{~d}(1.6)$ & $108.2 \mathrm{t}$ & $4.74 \mathrm{~d}(1.6)$ \\
\hline & & 4.80 br s & & $4.50 \mathrm{~d}(1.6)$ & & $4.45 \mathrm{~d}(1.6)$ \\
\hline 18 & $27.1 \mathrm{q}$ & $0.95 \mathrm{~s}$ & $22.7 \mathrm{q}$ & $1.22 \mathrm{~s}$ & $23.0 \mathrm{q}$ & $1.23 \mathrm{~s}$ \\
\hline \multirow[t]{2}{*}{19} & $64.9 \mathrm{t}$ & $3.36 \mathrm{~d}(11.2)$ & $64.1 \mathrm{t}$ & $4.17 \mathrm{~d}(11.2)$ & $64.2 \mathrm{t}$ & $4.18 \mathrm{~d}(11.2)$ \\
\hline & & $3.72 \mathrm{~d}(11.2)$ & & $3.30 \mathrm{~d}(11.2)$ & & $3.31 \mathrm{~d}(11.2)$ \\
\hline 20 & $15.3 \mathrm{q}$ & $0.62 \mathrm{~s}$ & $15.9 \mathrm{q}$ & $0.72 \mathrm{~s}$ & $16.2 \mathrm{q}$ & $0.72 \mathrm{~s}$ \\
\hline
\end{tabular}

${ }^{a}$ Multiplicities were obtained from DEPT experiments.

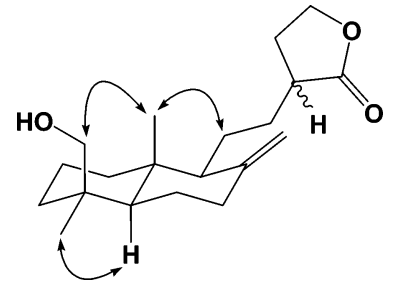

Figure 1. Key NOESY correlations for 1.

57.1, and C-18 at $\delta$ 27.1. The NOESY spectrum (Figure 1) confirmed that the C-20 methyl group, $\mathrm{H}_{2}-11$, and $\mathrm{H}_{2}-19$ are on the same side of the molecule. The C-13 stereochemistry is uncertain. On the basis of the above evidence, the structure of compound 1 was proposed as 19-hydroxylabda-8(17)-en-16,15olide.

Compound 2 was isolated as an amorphous powder. The molecular formula of $\mathrm{C}_{20} \mathrm{H}_{30} \mathrm{O}_{4}$ was determined on the basis of HREIMS and ${ }^{13} \mathrm{C}$ NMR data (Table 1). The IR absorption bands at 3381 and $1777 \mathrm{~cm}^{-1}$ indicated the presence of hydroxyl and $\gamma$-lactone functionalities. The ${ }^{1} \mathrm{H}$ NMR spectrum (Table 1) exhibited signals for two primary methyl groups $\left[\delta_{\mathrm{H}} 0.72\right.$ and $1.22(3 \mathrm{H}$ each, $\mathrm{s})]$ and two methylene protons linked to a $\gamma$-lactone group $\left[\delta_{\mathrm{H}} 4.23\right.$ $\left.(\mathrm{td}, J=8.4,6.8 \mathrm{~Hz}), \delta_{\mathrm{H}} 4.34(\mathrm{td}, J=8.4,3.6 \mathrm{~Hz})\right]$, a pair of terminal methylene protons $\left[\delta_{\mathrm{H}} 4.50\right.$ and $4.74(1 \mathrm{H}$ each, $\mathrm{d}, J=1.6$ $\mathrm{Hz})$, a pair of trans-coupling olefinic protons $\left[\delta_{\mathrm{H}} 5.50(\mathrm{dd}, J=\right.$ 15.6, 5.6 Hz) and $5.64(\mathrm{dd}, J=15.6,9.6 \mathrm{~Hz})]$, a carbinol proton $\left[\delta_{\mathrm{H}} 3.45(\mathrm{dd}, J=11.2,4.4 \mathrm{~Hz})\right]$, and two germinal carbinol protons $\left[\delta_{\mathrm{H}} 3.30\right.$ and $4.17(1 \mathrm{H}$ each, $\left.\mathrm{d}, J=11.2 \mathrm{~Hz})\right]$. The signals of the other methylene protons in the ${ }^{1} \mathrm{H}$ NMR spectrum were similar to those of $\mathbf{5} .{ }^{21}$ Compound $\mathbf{5}$ has one more double bond and, therefore, one more olefinic signal than 2 in the ${ }^{1} \mathrm{H}$ NMR spectrum. The ${ }^{1} \mathrm{H}$ NMR chemical shifts of $\mathrm{H}-11$ and $\mathrm{H}-12$ in 2 shifted to higher fields when compared to those of $\mathbf{5}$, and $\mathbf{2}$ had no significant absorption in its UV spectrum. In the HMBC spectrum of $\mathbf{2}$, the signal of $\mathrm{H}-3$ $\left(\delta_{\mathrm{H}} 3.45\right)$ correlated with those of $\mathrm{C}-18$ and $\mathrm{C}-19$ and indicated that the hydroxyl group is linked at C-3. The H-3 proton was assigned as axially oriented according to its observed coupling constants $(J=11.2,4.4 \mathrm{~Hz})$. In the NOESY spectrum, the proton signal of $\mathrm{H}-20$ showed correlations with $\mathrm{H}-11$ and $\mathrm{H}-19$, suggesting that $\mathrm{H}-11, \mathrm{H}-19$, and $\mathrm{H}-20$ are all $\beta$-oriented. The $\mathrm{C}-13$ stereochemistry again is uncertain. On the basis of the above evidence, compound 2 was proposed as 3 $\beta, 19$-dihydroxylabda-8(17), $11 E$ dien-16,15-olide.

Compound $\mathbf{3}$ was also isolated as an amorphous powder and assigned a molecular formula of $\mathrm{C}_{20} \mathrm{H}_{30} \mathrm{O}_{4}$ from HREIMS and ${ }^{13} \mathrm{C}$ NMR data. The IR absorption bands at 3391 and $1775 \mathrm{~cm}^{-1}$ confirmed the presence of hydroxyl groups and a $\gamma$-lactone group. As a result of the assignment of the HMBC and HMQC spectra, the gross structure of $\mathbf{3}$ was shown to be the same as that of $\mathbf{2}$. From the analysis of its NOESY spectrum, the relative configuration of the molecule and the side chain at C-9 was assigned as the same as $\mathbf{2}$. Analysis of all the data obtained suggested that $\mathbf{3}$ is the 13epimer of $\mathbf{2}$, and it was proposed as 13 -epi-3 $\beta, 19$-dihydroxylabda8(17),11E-dien-16,15-olide.

In the present study, primary cultures of neonatal cortical neurons from the cerebral cortex of Harlan Sprague-Dawley rat pups at postnatal day 1 were used as target cells. The effects of isolated pure compounds on $\mathrm{A} \beta_{25}-35$-treated cell apoptosis were determined by a MTT method for evaluating neuroprotective activity. Cortical neurons were incubated with vehicle $(0.1 \%$ DMSO) or various concentrations of the compounds for $2 \mathrm{~h}$ and then exposed to 5 $\mu \mathrm{M} \mathrm{A} \beta$ for $40 \mathrm{~h}$. The cell viability was assessed by MTT reduction analysis. Results showed that compounds $\mathbf{1}-\mathbf{5}$ reduced $\mathrm{A} \beta$-induced neurotoxicity in a concentration-dependent manner (Table 2). The compounds significantly protected neurons from $\mathrm{A} \beta$ damage by $25.3(\mathbf{1}), 29.5(\mathbf{2}), 36.7(\mathbf{3}), 28.9(\mathbf{4})$, and $29.5 \%$ (5), at concentrations of $5,10,10,10$, and $20 \mu \mathrm{M}$, respectively.

\section{Experimental Section}

General Experimental Procedures. Specific rotations were recorded on a JASCO DIP-1000 digital polarimeter. IR spectra were recorded 
Table 2. Protection of Cortical Neurons against $\mathrm{A} \beta$-Induced Cell Death by Selected Compounds from the Fruiting Body of Antrodia camphorata ${ }^{a}$

\begin{tabular}{ccl}
\hline $5 \mu \mathrm{M} \mathrm{A} \beta$ plus reagent & concentration $(\mu \mathrm{M})$ & cell death $(\%)$ \\
\hline $\mathbf{1}$ & 1 & $34.4 \pm 3.4$ \\
& 5 & $25.3 \pm 5.7^{* * * *}$ \\
& 10 & $28.1 \pm 5.7^{* * *}$ \\
$\mathbf{2}$ & 20 & $30.8 \pm 5.0^{* *}$ \\
& 1 & $43.8 \pm 9.5$ \\
& 5 & $34.9 \pm 2.6$ \\
$\mathbf{3}$ & 10 & $29.5 \pm 6.4^{*}$ \\
& 20 & $26.3 \pm 9.4^{* *}$ \\
& 1 & $45.1 \pm 3.5$ \\
$\mathbf{4}$ & 5 & $39.6 \pm 3.4$ \\
& 10 & $36.7 \pm 8.7$ \\
& 20 & $29.3 \pm 10.6^{* *}$ \\
$\mathbf{5}$ & 1 & $41.2 \pm 3.4$ \\
& 5 & $34.8 \pm 3.2$ \\
& 10 & $28.9 \pm 8.1^{* *}$ \\
Ac-DEVD-CHO & 20 & $32.6 \pm 7.2^{*}$ \\
& 1 & $40.7 \pm 3.3$ \\
& 5 & $35.7 \pm 1.9$ \\
vehicle (0.1\% DMSO) & 10 & $30.8 \pm 5.7^{* * *}$ \\
& 20 & $29.5 \pm 5.0^{* * *}$ \\
& 1 & $35.8 \pm 3.5^{* * *}$ \\
\end{tabular}

${ }^{a}$ Cortical neurons were incubated with vehicle $(0.1 \%$ DMSO), AcDEVD-CHO (caspase 3 inhibitor for the positive control), or compounds from Antrodia camphorata at the indicated concentration for $2 \mathrm{~h}$, then exposed to $5 \mu \mathrm{M} \mathrm{A} \beta_{25-35}$ for $40 \mathrm{~h}$. The cell viability was assessed by MTT reduction analysis. The data are means \pm SD of three independent experiments. Significant differences of cell death between cells treated with $\mathrm{A} \beta$ and $\mathrm{A} \beta$ plus compound are indicated by $* p<0.05$; $* * p<0.01$; and $* * * p<0.001$.

on a Perkin-Elmer $983 \mathrm{G}$ spectrometer. ${ }^{1} \mathrm{H}$ and ${ }^{13} \mathrm{C}$ NMR spectra were recorded on a Varian Unity Plus-400 spectrometer. EIMS and HREIMS were measured with JEOL Finnigan TSQ-46C and JEOL SX-102A mass spectrometers. Extracts were chromatographed on silica gel (Merck 70-230 mesh, 230-400 mesh) and purified on a semipreparative normal-phase HPLC column $[250 \times 10 \mathrm{~mm}$, Licrosorb Si $60(7 \mu \mathrm{m})]$ carried out with a LCD Refracto Monitor III.

Fungal Material. The fruiting bodies of A. camphorata (No. 2) were provided by Kang Jian Biotech Corp. Ltd., Nantau, Taiwan, Republic of China. The fungus was identified by one of the authors (M.-N.L.) A voucher specimen (No. 2) was deposited at Kang Jian Biotech Corp., Ltd., Nantou, Taiwan.

Extraction and Isolation. The dried fruiting bodies of A. camphorata $(2 \mathrm{~kg})$ were extracted with $\mathrm{MeOH}(40 \mathrm{~L})$ at room temperature $(5$ days twice). After evaporation, the residue of the $\mathrm{MeOH}$ extract was mixed with $\mathrm{H}_{2} \mathrm{O}$ to bring the total volume to $1 \mathrm{~L}$. This phase was extracted with $1 \mathrm{~L}$ of EtOAc (three times), the combined organic phase was evaporated, and the black syrup obtained $(150 \mathrm{~g})$ was chromatographed on silica gel eluting with hexane and EtOAc solutions. The fraction eluted with 30-40\% EtOAc in hexane was separated and purified by HPLC using a preparative silica gel column and a mixture of EtOAc-hexane (3:7) as eluent to give pure 1 ( $8.2 \mathrm{mg}, t_{\mathrm{R}}: 5 \mathrm{~min} 25$ $\mathrm{s}), 2\left(19.4 \mathrm{mg}, t_{\mathrm{R}}: 8 \mathrm{~min} 40 \mathrm{~s}\right), \mathbf{3}\left(3.0 \mathrm{mg}, t_{\mathrm{R}}: 8 \mathrm{~min} 45 \mathrm{~s}\right), \mathbf{4}(32.4 \mathrm{mg}$, $\left.t_{\mathrm{R}}: 5 \min 50 \mathrm{~s}\right), 5\left(5.5 \mathrm{mg}, t_{\mathrm{R}}: 9 \min 55 \mathrm{~s}\right), 14$-deoxyandrographolide $\left(6.2 \mathrm{mg}, t_{\mathrm{R}}: 9 \mathrm{~min} 10 \mathrm{~s}\right)$, and pinusolidic acid $\left(3.1 \mathrm{mg}, t_{\mathrm{R}}: 11 \mathrm{~min} 25\right.$ $\mathrm{s})$.

19-Hydroxylabda-8(17)-en-16,15-olide (1): amorphous powder; $[\alpha]_{\mathrm{D}}^{25}-17.5\left(c 0.62, \mathrm{CHCl}_{3}\right)$; IR (KBr) $v_{\max } 3470,2933,1772,1646$, 1448, 1381, 1156, $1030 \mathrm{~cm}^{-1} ;{ }^{1} \mathrm{H}$ and ${ }^{13} \mathrm{C}$ NMR data, see Table 1; EIMS m/z 320 [M] (4), 302 (8), 289 (42), 275 (16), 207 (22), 197 (100); HREIMS m/z 320.4716 (calcd for $\mathrm{C}_{20} \mathrm{H}_{32} \mathrm{O}_{3}, 320.4712$ ).

3ß,19-Dihydroxylabda-8(17),11E-dien-16,15-olide (2): amorphous powder; $[\alpha]^{25}{ }_{\mathrm{D}}+98.7\left(c \mathrm{0} 0.61, \mathrm{CHCl}_{3}\right)$; IR $(\mathrm{KBr}) v_{\max } 3381,2945,1777$, 1647, 1455, 1383, 1159, $1040 \mathrm{~cm}^{-1} ;{ }^{1} \mathrm{H}$ and ${ }^{13} \mathrm{C}$ NMR, see Table 1; EIMS m/z 334 [M] (12), 316 (10), 286 (15), 178 (28), 121 (100); HREIMS $m / z, 334.4539$ (calcd for $\mathrm{C}_{20} \mathrm{H}_{30} \mathrm{O}_{4}, 334.4546$ ). 13-epi-3 $\beta, 19$-Dihydroxylabda-8(17),11E-dien-16,15-olide (3): amorphous powder; $[\alpha]^{25} \mathrm{D}+11.6\left(c 0.79, \mathrm{CHCl}_{3}\right)$; IR $(\mathrm{KBr}) v_{\max } 3391,1775$, 1459, 1161, $1024 \mathrm{~cm}^{-1} 1 ;{ }^{1} \mathrm{H}$ and ${ }^{13} \mathrm{C}$ NMR, see Table 1; EIMS $\mathrm{m} / \mathrm{z}, 334$ [M] (12), 316 (18), 173 (33), 133 (44), 121 (100); HREIMS m/z 334.4557 (calcd for $\mathrm{C}_{20} \mathrm{H}_{30} \mathrm{O}_{4}, 334.4546$ ).

Neuroprotective Assay. Primary cultures of neonatal cortical neurons were prepared from the cerebral cortex of Harlan SpragueDawley rat pups at postnatal day $1 .{ }^{23}$ Briefly, each pup was decapitated and the cortex was digested in $0.5 \mathrm{mg} / \mathrm{mL}$ papain at $37{ }^{\circ} \mathrm{C}$ for $15 \mathrm{~min}$. The tissue was dissociated in Hibernate A medium (containing B27 supplement) by aspirating trituration. Cells were plated $\left(5 \times 10^{4}\right.$ cells/ $\mathrm{cm}^{2}$ ) onto poly-D-lysine-coated dishes and maintained in Neurobasal medium containing B27 supplement, 10 units $/ \mathrm{mL}$ penicillin, $10 \mathrm{mg} /$ $\mathrm{mL}$ streptomycin, and $0.5 \mathrm{mg} / \mathrm{mL}$ glutamine $\left(5 \% \mathrm{CO}_{2} / 9 \% \mathrm{O}_{2}\right)$ for 3 days. Cells were then exposed to cytosine- $\beta$-D-arabinofuranoside $(5$ $\mu \mathrm{M})$ for 1 day to inhibit proliferation of non-neuronal cells. The cells were used for the experiment on the fifth day.

Measurement of Cell Viability. The reduction of MTT was used to evaluate cell viability. Cells were incubated with minimum essential medium containing $0.5 \mathrm{mg} / \mathrm{mL}$ MTT for $1 \mathrm{~h}$. The medium was aspirated, and the formazan particle was dissolved with DMSO. The absorbance at $600 \mathrm{~nm}$ was measured using an enzyme-linked immunosorbent assay reader.

Statistical Analysis. Results are expressed as means \pm SD and were analyzed by ANOVA with post hoc multiple comparison with a Bonferroni test.

Acknowledgment. This research was supported by the National Science Council of the Republic of China (NSC 92-2321-B-002-006).

\section{References and Notes}

(1) Tsai, Z. T.; Liaw, S. L. The Use and the Effect of Ganoderma; SangYun Press: Taichung, Taiwan, 1982; p 116.

(2) Shen, Y. C.; Wang, Y. H.; Chou, Y. C.; Chen, C. F.; Lin, L. C.; Chang, T. T.; Tien, J. H.; Chou, C. J. Planta Med. 2004, 70, 310314.

(3) Hsiao, G.; Shen, M. Y.; Lin, K. H.; Lan, M. H.; Wu, L. Y.; Chou, D. S.; Lin, C. H.; Su, C. H.; Sheu, J. R. J. Agric. Food Chem. 2003, $51,3302-3308$.

(4) Shen, Y. C.; Chou, C. J.; Wang, Y. H.; Chen, C. F.; Chou, Y. C.; Lu, M. K. FEMS Microbiol Lett. 2004, 231, 137-143.

(5) Wang, G. J.; Tseng, H. W.; Chou, C. J.; Tsai, T. H.; Chen, C. T.; Lu, M. K. Life Sci. 2003, 73, 2769-2783.

(6) Liu, J. J.; Huang, T. S.; Hsu, M. L.; Chen, C. C.; Lin, W. S.; Lu, F. J.; Chang, W. H. Toxicol. Appl. Pharmacol. 2004, 201, 186-193.

(7) Nakamura, N.; Hirakawa, A.; Gao, J. J.; Kakuda, H.; Shiro, M.; Komatsu, Y.; Sheu, C. C.; Hattori, M. J. Nat. Prod. 2004, 67, 4648.

(8) Hseu, Y. C.; Chang, W. C.; Hseu, Y. T.; Lee, C. Y.; Yech, Y. J.; Chen, P. C.; Chen, J. Y.; Yang, H. L. Life Sci. 2002, 71, 469-482.

(9) Lee, I. H.; Huang, R. L.; Chen, C. T.; Chen, H. C.; Hsu, W. C.; Lu, M. K. FEMS Microbiol Lett. 2002, 209, 63-67.

(10) Chen, C. H.; Yang, S. W. J. Nat. Prod. 1995, 58, 1655-1661.

(11) Yang, S. W.; Shen, Y. C.; Chen, C. H. Phytochemistry 1996, 41, $1389-1392$.

(12) Cherng, I. H.; Chiang, H. C. J. Nat. Prod. 1995, 58, 365-371.

(13) Chiang, H. C.; Wu, D. P.; Cherng, I. W.; Ueng, C. H. Phytochemistry, 1995, 39, 613-616.

(14) Wu, D. P.; Chiang, H. C. J. Chin. Chem. Soc. 1995, 42, 797-800.

(15) Cherng, I. H.; Wu, D. P.; Chiang, H. C. Phytochemistry 1996, 41, 263-267.

(16) Shen, C. C.; Kuo, Y. C.; Huang, R. L.; Lin, L. C.; Don, M. J.; Chang, T. T.; Chou, C. J. J. Chin. Med. 2003, 14, 247-258.

(17) Han, B. H.; Yang, H. O.; Kang, Y. H.; Suh, D. Y.; Go, H. J.; Song, W. J.; Kim, Y. C.; Park, M. K. J. Med. Chem. 1998, 41, 26262630

(18) Matsuda, T.; Kuroyanagi, M.; Sugiyama, S.; Umehara, K.; Ueno, A.; Nishi, K. Chem. Pharm. Bull. 1994, 42, 1216-1225.

(19) Lomlim, L.; Jirayupong, N.; Plubrukarn, A. Chem. Pharm. Bull. 2003, $51,24-26$

(20) He, X. J.; Li, J. K.; Gao, H.; Qiu, F.; Cui, X. M.; Yao, X. S. Chem. Pharm. Bull. 2003, 51, 586-589.

(21) Reddy, M. K.; Reddy, M. V. B.; Gunasekar, D.; Murthy, M. M.; Caux, C.; Bodo, B. Phytochemistry 2003, 62, 1271-1275.

(22) Chiang, Y. M.; Liu, H. K.; Lo, J. M.; Chien, S. C.; Chan, Y. F.; Lee, T. H.; Su, J. K.; Kuo, Y. H. J. Chin. Chem. Soc. 2003, 50, $161-166$.

(23) Wang, C. N.; Chi, C. W.; Lin, Y. L.; Chen, C. F.; Shiao, Y. J. J. Biol. Chem. 2001, 276, 5287-5295.

NP0581263 